\title{
Defining and Achieving Success in the Movement to Change Scholarly Communication
}

\section{By Joyce L. Ogburn}

In the pursuit to change scholarly communication, libraries have undertaken a number of initiatives. These may include establishing a formal program, creating a committee, or taking other concerted actions at their institutions. While librarians have been engaged in targeted activities for some time, there has been no attempt to describe what constitutes a successful program. This paper proposes that five stages that are experienced in organized attempts to change scholarly communication, arguing that the use of stages provides a practical approach to addressing a nearly intractable problem. The author defines these stages, offers illustrative examples, provides measures of success, and details strategies that support the efforts toward change.

Joyce L. Ogburn (joyce.ogburn@utah. edu) is Director, J. Willard Marriott Library, University of Utah, Salt Lake City.

Submitted June 20, 2006; tentatively accepted pending revision August 4, 2006; revised and resubmitted July 13, 2007, and accepted for publication.

The genesis of the ideas discussed in this paper grew out of the author's presentation, "Scholarly Communications: From Awareness to Understanding to Ownership," at the Association of Library Collections and Technical Services Scholarly Communications Discussion Group, American Library Association Midwinter Meeting, Philadelphia, January 27, 2003. Versions of this paper have been distributed at the Association of College and Research Libraries/Association of Research Libraries Institutes on Scholarly Communication.

\section{Defining and Achieving Success in the Movement to Change Scholarly Communication}

Over the last few decades, the system of scholarly communication-the creation and dissemination of the products of research and learning-has been perceived by many librarians and scholars as approaching a crisis point. They have challenged the prevailing culture and methods of scholarly communication as library acquisitions budgets have decreased, prices for journals have risen, monograph purchases have declined, the economic underpinnings of publishing have changed, the use of licensing has risen, access to scholarship has been curtailed or lost, and advancing technology has posed new challenges and opportunities. One primary response of libraries has been to initiate a local program or charge a committee to lead local efforts with the hope of achieving revolutionary change throughout scholarly communication. Library professional associations and other organizations such as the Association of Research Libraries (ARL) and the Association of College and Research Libraries (ACRL) have initiated programs as well. As yet, no attempt has been made to delineate clear indicators of success of these programs. This paper will propose and define a series of stages that a library program may experience, describe the markers of success, and suggest strategies that may lead to fundamental change.

Defining stages is one method used to understand personal, social, or programmatic evolution or change. One could argue that scholarly communication 
programs established by libraries will advance through a series of stages before achieving real and lasting change. Defining and applying the concept of stages to scholarly communication can help establish and guide a program by setting directions and goals, tracking progress, identifying landmarks, and noting achievements.

This paper proposes five stages, starting with creating awareness and progressing to achieving transformation. The stages reflect an evolution from local action to collaborative efforts, with the goal of achieving widespread change. Most scholarly communication programs initially will concentrate on local efforts and strategies, but in time they should build broad-scale coalitions of organizations and individuals that share the desire to create new models of scholarly communication. Tying changes directly to any single action, initiative, or program can be difficult; progress tends to proceed unevenly, and social change is a disorderly process. Local actions, however, can lead to global changes. As programs mature, they will expand their agendas and activities beyond their local institution and, as the rhetoric grows more sophisticated, the evidence of unsustainability more apparent, the arguments more persuasive, and the authors more moved to action, library programs will gain greater results. In the following exploration of the stages, the author suggests that local programs may produce the most viable and visible systemic change only by engaging professional associations, consortium partners, scholars, scholarly societies, publishers, and other stakeholders.

\section{Stages: From Awareness to Transformation}

The five stages proposed are awareness, understanding, ownership, activism, and transformation. For the purposes of this paper, the following definitions will be used. Awareness means being conscious and having knowledge of issues. Understanding represents a higher order of knowledge, intelligence, and appreciation. Ownership connotes commitment and obligation. Activism is goal-directed, concerted, and purposeful action. Transformation equates to attainment of a profound alteration of assumptions, methods, and culture.

The following section applies these definitions to the problem of scholarly communication and describes the characteristics of each stage, accompanied by markers of success and examples that illuminate the conceptual model of each stage. Although many libraries are able to determine how to create awareness and some degree of understanding on campus, some markers for success are worth noting. Not all libraries have launched programs and many others are in early development stages or have informal initiatives. The difficult transitions are moving from understanding to ownership and then on to activism and transformation. Given these assumptions, this paper will briefly describe success in achieving awareness and understanding, and then will focus on the attributes that mark progress in the latter stages.

\section{Awareness}

During awareness, the issues connected with scholarly communication are perceived in simple terms of high prices and constrained budgets. Librarians have knowledge of the underlying problems and infrastructure of scholarly communication and track new developments. They may lay the blame for the problems on publishers and publishing practices. Scholars and administrators are acquainted with the issues, key points, and rhetoric. At this stage, the challenges associated with high inflation and serials pricing generally are perceived as confronting the library, not the academy and the parent institution. Absent is recognition of the complexity of the problems permeating the overall system.

Awareness is the early knowledge that a problem exists; the nature of the problem is still being formulated and the issues framed. Journal pricing is seen to be the main issue to be addressed. Librarians may be the most knowledgeable players at this stage and begin to share their concerns and observations with others. This stage is marked by complaints and limited conversations, but concentrated efforts are put toward researching and comprehending the problem. Faculty and administrators may listen to what librarians have to say, but the issues do not have meaning for them yet.

\section{Understanding}

As awareness gives way to understanding, scholars fully appreciate the challenges and relate them to their discipline or areas of interest. They are able to discuss the basic issues and repeat well-known facts. They realize that the practices underlying scholarly communication and publishing affect access to scholarship. The problem still may be seen as one primarily confined to the library. Academic administrators express concern, but take no action and provide little concrete support for challenging the practices that have produced and underlie the issues. In the library, concern becomes alarm, as the implications of what is termed "the serials crisis" affect every function and unit. Librarians recognize that the issues extend beyond journal prices and that authors also are integral to the structure and function of the publishing enterprise.

As the stage where knowledge finds a foothold, understanding is demonstrated by articulation of the scope and underlying causes of the problematic aspects of scholarly communication, greater analysis and comprehension, the initiation of forums on campuses, and the beginning of library programs. When understanding emerges, the infor- 
mation propagated by librarians is grasped by faculty and administrators, who recognize the many factors that contribute to the function of scholarly communication and who begin to restate the issues in their own terms.

\section{Ownership}

During the ownership stage, scholars, administrators, and librarians increase in their engagement with the issues. The results of librarians' efforts to foster awareness and understanding start to bear fruit. Scholars speak on behalf of solving the problem, and are personally and acutely cognizant of how the system functions in their discipline and across the wider scope of scholarship. They acknowledge that the problem is not solely the libraries and that all the participants have a role in what is happening in scholarly communication. Academic administrators lead discussions of issues and provide support for activities directed toward achieving change. Librarians realize that they are contributors to the workings of the system and start advocating for change at their institutions.

Ownership is marked by the recognition and acceptance that the players in scholarly communication all share responsibility and a stake in a healthy system. With ownership comes motivation and the resulting power to make a difference. This is the stage where librarians make a large-scale programmatic commitment to addressing issues of scholarly communication within their institutions and their professional organizations. Recognizing the acute need for a coordinated effort, the ARL established the Office of Scientific and Academic Publishing in 1990; the name was changed in 1995 to the Office of Scholarly Communication. ${ }^{1}$ In 1998, ARL founded the Scholarly Publishing and Academic Resource Coalition (SPARC). ${ }^{2}$ Both of these organizations have played a substantial role in supporting and leading change.

When faculty achieve ownership, they have a "eureka" moment, realizing that their scholarly and personal practices connect directly to the problems manifested in high prices, the cancellation of journals, loss of access to important research, and the decrease in library acquisition of other scholarly resources. Enlightened self-interest takes hold and they become motivated to do something to ameliorate the problem. Academic administrators are also in step with librarians in the call for change. Evidence for congruence of thinking occurred in March of 2000, when a group of academic administrators and librarians came together in Tempe, Arizona, at a conference sponsored by the Association of American Universities, the ARL, and the Merrill Advanced Studies Center of the University of Kansas. This group formulated "Principles for Emerging Systems for Scholarly Publishing," which became known as the Tempe Principles. ${ }^{3}$
Ownership is evident when faculty members invite librarians to speak to them about scholarly communication, and they take a stand to refuse to support particular journals or publishers. Scholars agree to participate in meetings sponsored by libraries or library professional organizations, such as the ACRL SPARC forums held at the American Library Association (ALA) conferences. Supporting and encouraging the creation of scholarly communication committees, task forces, targeted programs, discussion groups, or interest groups within scholarly societies (and attendance of faculty members) are indications of ownership. In 2001, the American Anthropological Association (AAA) established a Librarians Advisory Group to advise the publications program. In 2002, the AAA created a Scholarly Communication Interest Group, and in 2003 the association selected Suzanne Calpestri, the John H. Rowe Librarian at the University of California, Berkeley, to chair the AnthroSource board. This working relationship may not be as close as it was. In 2006, the staff of the AAA and the AnthroSource Steering Committee, composed of librarians and anthropologists, differed on support of the Federal Research Public Access Act (FRPAA). ${ }^{4}$ The Libraries Division of the American Society for Engineering Education also maintains a Scholarly Communication Committee. ${ }^{5}$

Another encouraging signal of ownership is faculty hosting events without prompting from librarians. Applied Mathematics faculty and graduate students at the University of Washington (UW) held a discussion on scholarly communication on May 25, 2004. Martha Tucker, Math Library, and Carl Bergstrom, Biology Department, were invited to speak about the issues from their perspectives at this event, which led to the decision to create an applied math community in the UW Libraries' DSpace repository. By coincidence, one week later the UW Graduate Department of Neurobiology and Behavior held a forum about open access, with Hemai Parthasarathy, senior editor of the Public Library of Science, as the featured speaker. This discussion covered many facets of scholarly publishing, including copyright, whether the author should pay for publishing a paper, the costs of publishing, peer review, and the like.

\section{Activism}

In activism, ownership evolves into actions to make the system sustainable, to create new models, and to take responsibility for change. During this stage, activists successfully recruit external allies to take action and librarians collaborate to employ common and coordinated strategies. Collaborative action is demonstrated by the formation of dedicated advocacy groups, such as the Open Access Working Group and the Alliance for Taxpayer Access. ${ }^{6}$ As activists, librarians use their collective power to share information about vendor and publisher contracts and 
offers, negotiate for terms that meet library values, and work to relax restrictive agreements. ${ }^{7}$ Publishers join libraries to reconceive their services in response to input from the scholarly community regarding pricing, copyright, and access. An example of a cooperative venture is the partnership of SPARC, the Greater Western Library Alliance (GWLA), and scholarly societies with Allen Press to create BioOne, a collection of journals in nonhuman biology. ${ }^{8}$

Scholars and administrators invest in and are committed to achieving a positive change in their own culture and practices. In recognition of the strategic significance of a healthy scholarly communication system, the institution dedicates substantial resources, time, and attention to internal initiatives and analyses. Support is given for library actions that directly challenge publishing practices that lead to high prices and inhibit wide access to scholarship. One such mark is when faculty senates, councils, and committees take actions that show solidarity with librarians in rejecting pricing models and licensing terms that are undesirable. In 2003 and 2004, with the support of their faculty governance organizations, several libraries declined to continue their package subscriptions (often called Big Deal or bundled subscription packages) to Elsevier's Science Direct or other high priced packages of journals. Among these libraries are those at Cornell University, North Carolina State University, and Indiana University. ${ }^{9}$

Rewards, recognition, and incentives for faculty contributions to change are provided by the institution. Experiments with digital formats enter the mainstream and are made widely available through the Internet. With the growth of new media and experimentation in digital technologies, policies and reward structures begin to reflect new thinking and perspectives on what comprises quality scholarship. The report of a 2003 summit held by the Committee for Institutional Cooperation (CIC) indicates that the CIC institutions have widened their definitions of scholarship and are accepting for promotion and tenure the scholarship created and disseminated by digital technologies. ${ }^{10}$

At this stage, academic administrators provide new funding and resources to foster new forms of scholarship, and are willing to create institution-wide initiatives that put substantial effort toward solving the problems of the present system. An example can be an institution-level committee. Several of these composed both of librarians and faculty members have existed: the University of Tennessee Scholarly Communications Committee, the Indiana University Committee on Scholarly Communication, the University of Arizona Senate Committee on Intellectual Property and Scholarly Communication (no longer active), and the Cornell University Scholarly Communications Council. ${ }^{11}$

As ownership grows into activism, more people across an institution are willing to lend their time and professional reputations to the cause. They lobby for changes to guidelines, policies, bylaws, and practices at the institutional or organizational level. Scholars employ their particular expertise to examine and write articles about the problems of scholarly communication. Many scholars and librarians write letters and sign initiatives and declarations in support of new models, such as the Budapest Open Access Initiative, which began in $2001 .^{12}$ Further, librarians, faculty, administrators, and lobbyists work together to influence or formulate legislation or other high-impact actions that will create and instill new models at a regional or national level. ACRL, ARL, and SPARC have been effective in garnering support for legislation encouraging or mandating that results from federally funded research be made publicly available, such as the National Institutes of Health Public Access Policy. ${ }^{13}$

Activism is evident when faculty members research the causes and effects of the problems of scholarly communication in their field and widely share their results with colleagues, as Barschall did in the 1980s. ${ }^{14}$ Scholars who have tackled the issues of scholarly communication include Peter Suber, who founded the Free Online Scholarship Newsletter (now the SPARC Open Access Newsletter); Theodore Bergstrom and Carl Bergstrom, authors of tools and studies; and Mark McCabe, who has written from the perspective of an economist. ${ }^{15}$

Scholars follow through on their declarations and signatures of support by altering their long-standing publishing, reviewing, and editing practices, and they advocate for others to follow suit. Authors take steps to retain copyright to their work and, in addition, they begin to deposit copies in a subject-based or institutional digital repository. The advent of digital repositories dates back to the 1990s with the beginnings of the subject-based preprint services developed by scholars. Paul Ginsparg launched ArXiv, the physics preprint server, in $1991 .{ }^{16}$ Libraries and their partners later began earnest work in this area, developing and sharing repository software such as DSpace (MIT) and Fedora (Cornell University). ${ }^{17}$ On the publishing front, editorial boards and societies persuade their publishers to reduce the price of their journals and maintain control over future pricing. In 2000, the American Association of Physical Anthropologists negotiated with Wiley for a substantial decrease in price for their journal, the American Journal of Physical Anthropology ${ }^{18}$ Editorial boards may even leave their publishers over disagreements regarding pricing or publishing policies and start new journals. The board of Machine Learning resigned and started the Journal of Machine Learning Research in $2000 .^{19}$ Foundations and funding agencies that desire to be part of the solution also contribute to activism by supporting research and projects. The Andrew W. Mellon Foundation has a long-standing interest in scholarly communication and has been instrumental in documenting the issues, promoting experimental models, and fostering new kinds of scholarship. An early 
examination and analysis of the issues, conducted with ARL, led to the publication in 1992 of the landmark work, University Libraries and Scholarly Communication: A Study Prepared for The Andrew W. Mellon Foundation. ${ }^{20}$ The Mellon Foundation has provided funding to incubate new models and support systems for scholarly communication such as the DSpace Federation and the development of DPubS, an open-source software-publishing system being developed by Cornell University Library and the Penn State University Libraries and Press with a coalition of partner libraries. ${ }^{21}$ Local programs can advance their agendas by seeking support from those in the funding community that have demonstrated commitment to creating change.

\section{Transformation}

Transformation requires profound, systemic, and far-reaching change. The ultimate goal of any library program should be to advance and sustain the transformation of the library community as well as the local institution, scholarship, and the publishing industry to benefit a global community of stakeholders. Local programs at the transformation stage are well-engaged with rapidly evolving scholarship, but at some point after achieving their original purpose they may disband, merge into a larger effort, or assume a new role. At this writing it is unlikely that many, if any, local programs are solidly at stage four, let alone stage five. Transformation cannot be achieved by a solitary library or single approach; it demands collaboration, matured and advanced by earlier stages, by many stakeholders to achieve a shared vision. The collaborative pursuit of transformative change is still evolving.

For scholarly communication, this final stage is a shift in culture, a new state of being, and, at this point in time, an idealized conceptual model. With scholarly communication in a state of transition, predicting the course and outcome of transformation is difficult. Although its exact form is hard to foresee, transformed scholarly communication likely will be characterized by experimentation and multiple, diverse approaches. In a transformed state, new models will emerge and flourish. New practices of scholarship promote further innovation, provide rewards and incentives, and are affordable, sustainable, and available to a global scholarly readership. Global access to scholarship may be perceived as a common good for all people. Partnerships connect communities of scholars, librarians, administrators, and publishers in creating, accessing, understanding, and preserving new kinds of scholarship. Enabled by digital technologies, methods and modes of dissemination meet the needs of disciplines and fields and offer dynamic new ways of engaging with the results of scholarly activities. Librarians have gained additional roles in supporting the life cycle of scholarship, and resources are reallocated in response. Respectful and productive dialogue occurs between librarians, authors, societies, and publishers as they work together on advancing a healthy system. Given the dynamic nature of scholarship and the rapid advance of technology, transformation may be a process that continues well into the future.

At this stage, the library itself will be transforming as it is integrated into new kinds of scholarly activities by reconceiving its services. Some indicators worth noting demonstrate transformation is occurring. Using digital library development as a catalyst and host for new models of the creation and dissemination of scholarship signals a profound shift in library services. Many libraries have changed the direction of their digital library programs from digital reformatting of special collections materials to promoting change in scholarly communication with projects such as digital repositories and electronic publishing. Institutional repositories with regular contributors and growing content are a sign of change. Early implementers of digital repositories included Massachusetts Institute of Technology, the University of Rochester, and the California Institute of Technology, and the number of repositories has been growing rapidly. With repositories and refocused digital services in place, librarians are able to engage with scholars in imagining, creating, describing, disseminating, and preserving new knowledge. The California Digital Library eScholarship program is one of the more robust and ambitious programs in the United States that promotes and supports new forms of scholarship and knowledge from creation all the way through peer review, management, dissemination, and preservation. ${ }^{22}$ Examples of libraries embracing electronic scholarly publishing include Highwire Press at Stanford University, Project EPIC at Columbia University Library, the Scholarly Publishing Office at the University of Michigan Library, and Project Euclid at the Cornell University Library. ${ }^{23}$

Librarians also quickly identify the emergence of important initiatives and offer their resources and talents to support their development by forging partnerships with their local university presses. In March 2005, the University of Utah Press became part of the J. Willard Marriott Library. At the Penn State University, the libraries and the university press are collaborating to form new models for disseminating scholarship and, in December 2006, the press joined the libraries. ${ }^{24}$ Also in 2006, Syracuse University Press came under the direction of the University Librarian and Dean of Libraries. The university press has been a component of the library at Purdue University for some time.

New models and publications that are created and led by scholars, along with open access becoming a mainstream movement, indicate a commitment to change beyond activism. The ArXiv physics preprint service mentioned earlier, was launched at the Los Alamos Laboratory. It was supported by the Laboratory's library until its founder moved to Cornell University in 2001 and the library there took on 
responsibility for its maintenance. ${ }^{25}$ Among the scholar-led publications is the Public Library of Science. ${ }^{26}$ Many of the publications listed in the Directory of Open Access Journals were created by faculty. ${ }^{27}$ Faculty members at the University of California at Berkeley founded the Berkeley Electronic Press (bepress) to provide a platform for publishing new electronic journals. ${ }^{28}$ Transformation is also demonstrated when new institutionally owned journals or societal publications that provide lower prices and wider access are successfully established. SPARC maintains a list of these journals and of initiatives with which they have partnered. ${ }^{29}$ Scholars mount challenges to restrictive ideas of intellectual property, such as the Creative Commons, offering a glimpse into a new way of publishing scholarship. ${ }^{30}$ When transformation occurs, inspired and innovative forms of research and learning represent new standards for respected scholarship. ${ }^{31}$

One vision of transformation comes from Unsworth and $\mathrm{Yu}$, who propose the following description of what scholarly communication should look like in the year 2010: "In a better world, high-quality, peer-reviewed information would be freely available soon after its creation; it would be digital by default, but optionally available in print for a price; it would be easy to find, and it would be available long after its creation, at a stable address, in a stable form. ${ }^{32}$ While this description may not sound like a radical overturning of the current model, it is a worthy aspiration and a view that is at the leading edge of transformation.

In another provocative article, "Rethinking Scholarly Communication: Building the System that Scholars Deserve," Van de Sompel et al. dissect and distill the process of scholarly communication into the activities of registration, certification, awareness, archiving, and rewarding. This article suggests "a revised perspective on what constitutes a unit of communication in a future scholarly communication system." ${ }^{33}$ The authors propose that:

- The system should consider datasets, simulations, software, and dynamic knowledge representations as units of communication in their own right.

- The system should accommodate complex documents that flexibly aggregate the products of the scholarly endeavor, regardless of their format or location. These compound objects must themselves be considered units of communication and therefore be recursively available for inclusion into other compound units. Such technology would provide for the reuse and derivation of existing results that is an integral part of the scholarly process.

- "The system must facilitate the early registration (and ultimately preservation) of all units in the system, regardless of their nature or stage of development. This would facilitate collaborative networkbased endeavors and increase the speed of discovery.
Preprints, raw datasets, prototype simulations, and the like should be afforded the ability to proceed through the scholarly value chain in the same manner that only journal publications are afforded in the current system." 34

The concept described above leaps beyond traditional publishing and envisions the capture and nurturing of a far larger scope of scholarly activities.

As said before, transformation may be considered an ideal. In the case of scholarly communication, transformation could equate with access by the public to the products and outcomes of scholarship being treated as a common good — shared and beneficial to all—and a strategic value of a democratic society. In this scenario, ownership of knowledge would not be confined to the few, but shared by many. Perhaps each discipline will have defined and optimized its practices in networked, collaborative, and digital space. At the very least, a critical mass of change should have occurred, giving birth to a new system that brings innovative and tangible benefits to the entire group of stakeholders in scholarly communication.

One might ask whether all five stages must be experienced in sequence by any program. The answer is probably no-change is rarely simple or entirely unilateral or unidirectional. Most likely, multiple stages are experienced simultaneously and this will vary by institution and disciplines. Still, the application of the concept of stages helps gauge the progress of a formal program and provides useful reference points and language.

\section{Strategies for Success}

How can libraries help bring about change? Many fruitful strategies can be employed to move from awareness to transformation. A library must create a cohesive program, develop a unified vision, foster ongoing and productive conversations, forge new relationships, and maintain momentum. In 2003, the Scholarly Communication Committee of ACRL endorsed strategies for system reform, including creating competitive journals, challenging the merger of publishing houses, supporting open-access journals, advocating for federal legislation, developing institutional repositories, ensuring preservation, and the like. ${ }^{35}$ This paper identifies a different set of strategies that amplifies and complements those outlined by the ACRL committee.

Institutional scholarly communication programs likely will move through these stages at different rates. Strategies should be used within the context of the institutional situation, recognizing the resources available and the importance given to achieving change in scholarly communication. The strategies proposed here can be applied at almost any of 
the stages, depending on whether a program exists, how advanced or mature the program is, the likely reception on campus, and the nature of the established goals. A scholarly communication program should employ strategies that make sense locally; however, it should encompass the elements of leadership (individual and organizational); communication, outreach, education, and advocacy; research; coalition building; resource allocation; and assessment.

\section{Strategies for Leadership}

A key initial step is for a person who has resources and authority to assume leadership, responsibility, and coordination for the program. Relying on a lone voice to speak and act for the library is not enough; a program has to recruit many people to speak eloquently and take direct action on the issues. A committee may be charged to oversee the program and carry out specific tasks. Examples of library committee charges include the North Carolina State University Scholarly Communication Subcommittee of the University Library Committee, now discharged, and the University of Washington Scholarly Communications Steering Committee. ${ }^{36}$ If so, this group should research and analyze the local situation; gather data; develop appropriate strategies, goals, policies, and an action agenda; set timelines; and determine outcomes that will lead to change. The designated leader and the committee together can develop the program in ways that motivate and engage others. One way to grow leadership capabilities is to attend the ACRL/ARL Scholarly Communications Institute, which is designed to foster a team leadership approach to developing a new program or enhancing an existing one ${ }^{37}$ It provides the training and tools to craft a campus-specific plan.

\section{Strategies for the Program}

An important piece of a program is a plan for communication, outreach, education, and advocacy. The scholarly communication committee may have this responsibility. Methods might include creating a Web site, developing talking points that include local and national data for librarians to share with their faculty counterparts, and planning campus forums and conversations. People who are passionate about scholarly communication and well-versed in the issues and trends may forget that not all librarians are as informed and ready to speak persuasively on the issues when opportunities arise. Librarians need to be prepared with information and tools to contribute effectively to advancing the program. An educational strategy should be at the heart of any program. A good tool to employ for education was developed by the ACRL Scholarly Communication Committee to reach librarians, authors, and administrators. ${ }^{38}$ ARL has created guides for holding "Brown Bag Lunches" for engaging staff. ${ }^{39}$ A local committee should also monitor local, national, and international developments within the broad area of scholarly communication, and share this information with others. The SPARC Web site is a useful source of current information. ${ }^{40}$ The committee should identify the faculty at its institution who hold editorial positions, and seek out the scholars who have already embraced ownership or activism to help influence the opinions and actions of these editors.

Gaining the attention of the faculty and administrators and engaging them in productive discussion and partnership will be a challenge. A program has to balance carefully the amount of information delivered. If faculty and administrators are given too much information, they may ignore the message; given too little, they may not listen. Librarians must be prepared to deliver the right information at the right time. Faculty in library advisory groups and the academic senate may be receptive to assisting in the crafting and delivery of a persuasive message.

Distributing information in widely disseminated campus publications can be a powerful part of a communication plan. The committee could be employed to write a regular column or newsletter for local distribution and to get information into other campus publications. Articles should be to the point, stripped of jargon, and written with the perspective of the audience in mind. An even more influential approach would be to have faculty activists write and share their ideas, motivations, and experiences in regard to changing scholarly communication. To keep messages current, librarians should distill news items and send them to faculty and administrators with regularity. Many library newsletters publish articles on scholarly communication to raise awareness of their programs and concerns. The Hardin Library for the Health Sciences at the University of Iowa publishes a newsletter devoted to scholarly communication. ${ }^{41}$

Creating partnerships and building coalitions are essential elements of success. If a program involves scholars and administrators in meaningful ways, they will be more likely to continue as allies and partners in change. The committee can prepare librarians and faculty to present briefings at faculty department meetings, orientation sessions, and governance groups. If the library has an advisory council composed of faculty, this council can be enlisted to act and speak on behalf of change. Workshops dedicated to getting published are another opportunity for talking about the health of scholarly publishing and the impact of decisions authors can make on publishing. Like librarians, faculty advocates will need information and tools to advance the goals of the program.

Other effective strategies with faculty include discovering their concerns, interests, and the motivations that will encourage them to support transformation. A library program may serve as a catalyst for faculty partnerships and lead to experiments and alternatives to traditional scholarly communication venues. These include creating subject 
repositories, supporting online working or technical papers series, managing electronic theses and dissertations, conducting joint digitization projects, preserving course Web site content, and archiving data. The library also could publish or serve as an archive for a faculty member's journal.

Library policies, guidelines, decisions, and practices are integral to the performance of the present system of scholarly communication. As the ACRL Scholarly Communication Committee pointed out in their list of strategies, a program should employ the power present in collaborative libraries groups (for example, organizations, consortia, societies, or associations). The scholarly communication program should be active in determining the direction, policy, and goal setting of these groups. Consortia can be used to stand firm when seeking terms that advance the cause of open information and open scholarship. Adhering to shared and strong principles in the negotiation and acquisition of published material is critical-progress cannot be made if librarians give away their rights and agree to restrictive terms that limit the ability to share information and work in collaboration. One of the greatest powers librarians have is the ability and motivation to share information. Maintaining an open flow of information is crucial; collective knowledge combined with collective action is very powerful.

Another strategy is to allocate resources to support change initiatives, in whatever form they may take. The funding may come initially from internal reallocation, but soliciting and securing funding from the institution or an external funding organization is crucial to establishing new services and implementing fresh approaches. Effecting change and putting in place the underlying structures required to respond to new models is an investment in the future. The scholarly communication committee could be asked to make recommendations or decisions about the allocation of resources to support initiatives and actions directed toward effecting change.

Another important partner in change is the publisher. In conversations about scholarly communication among librarians, the publisher is often assigned the role of the adversary, which is unfair to the many publishers that have worked with scholars and librarians to experiment and explore new territory. Societies and associations that maintain their own publishing programs have not followed equal paths, and commercial publishers are not all alike. The university press is a potential ally and supporter. Someone from the library might serve on the press board (or conversely, someone from the press could serve on library committees or advisory groups), and partnerships could blossom through pursuing joint publishing ventures. University presses are seeking their place in the digital world and may be eager to try different means of achieving their goals.

A new perspective on the library's role in scholarly communication must be embedded in library programs, practices, and funding models. The development of digital libraries presents an enormous opportunity to provide programmatic direction and resources toward change. Many scholars are pursuing scholarship that is digital in nature and that does not lend itself to the traditional paths of dissemination. Librarians should assist with the development of this new scholarship and link it to their scholarly communication programs. Digital scholarship is thriving at the California Digital Library's eScholarship program and the Institute for Advanced Technology in the Humanities (IATH) at the University of Virginia. ${ }^{42}$ The Cornell University Library offers to its faculty the Digital Consulting and Production Services (DCAPS). ${ }^{43}$ A number of commercial and open-source products have evolved that help manage the creation, dissemination, and curation of scholarship from formal publication to digital repository management. These include e-prints, DSpace, Fedora, CONTENTdm, bepress, and Digital Commons. Literature describing digital scholarship and presenting interesting support models is relatively recent but growing. Publications on digital scholarship include Andersen's Digital Scholarship in the Tenure, Promotion, and Review Process, Ogburn's "Digital Scholarship," Unsworth's "The Crisis in Scholarly Publishing in the Humanities," and Smith's New Model Scholarship: How Will It Survive. ${ }^{24}$ The UW maintains a Web site devoted to digital scholarship. ${ }^{45}$

Essential to success is having the faculty members who create scholarly materials pursue and lead initiatives; substantial and sustainable change will not occur without the whole-hearted endorsement and leadership of the authors themselves. A program should aim to bring fundamental and widespread change to fruition, perhaps led by an institutional, campuswide committee reporting to the chief academic or administrative officer, or to the faculty governance organization. Libraries should solicit authors and administrators to join national advocacy initiatives by writing to legislators or lending support to lobbying activities.

\section{Conclusion}

This paper has proposed that five stages-awareness, understanding, ownership, activism, and transformation — are associated with achieving change in scholarly communication and are characterized by increasing levels of understanding, commitment, and engagement. Attributes and markers of a successful program have been outlined and a number of strategies have been recommended for libraries to implement and sustain a scholarly communication program. The pursuit to redefine and radically change the conduct and dissemination of scholarship will be difficult. For library programs, maintaining optimism, courage, and momentum are important, as are winning and keeping allies. 
Programs may begin with local focus and strategies, but ultimately they must attain a wider sphere of influence; transformation will be achieved only through building effective collaborations and coalitions. The best possible outcome to scholarly communication programs would be one in which all stakeholders can share and strive for the same vision. All parties have contributed to the present state of scholarly communication. Ideally, success in achieving a new vision will come about through multifaceted approaches, productive and respectful conversations, cooperation, and good faith among all interested parties. Achieving this kind of working relationship should be a primary goal of the library, publishing, and scholarly communities.

Transformation is attainable, but still far off. As Lao Tzu is purported to have said, "a journey of a thousand miles begins with a single step." Librarians are the "canary in the coal mine," forecasting the danger of leaving current practices unchallenged, and highly motivated to conduct programs designed to create fundamental and lasting change. ${ }^{46}$ It would be wise to heed the writings of John Kotter, noted author on leadership in business, who emphasizes that transformations fail when organizations do not persevere in seeing the process through to conclusion. ${ }^{47}$ Libraries are advocating transformation - the time has come for them to assess their progress and strengthen their strategies toward achieving new and sustainable practices, systems, and models of scholarly communication.

\section{References}

1. Lee Anne George and Julia Blixrud, compilers, "Association of Research Libraries: A Brief History," in Celebrating Seventy Years of the Association of Research Libraries, 1932-2002 (Washington D.C.: Association of Research Libraries, 2002), 8.

2. SPARC: The Scholarly Publications and Academic Resources Coalition, www.arl.org/sparc (accessed Aug. 29, 2006).

3. Association of Research Libraries, Tempe Principles for Emerging Systems of Scholarly Communication, www.arl .org/resources/pubs/tempe/principles-2.shtml (accessed July 11, 2007).

4. Suzanne Calpestri, chair, AnthroSource Steering Committee, to Alan Goodman, president, American Anthropological Association, and Deborah Heath, chair, American Anthropological Association Committee on Scientific Communication, Aug. 9, 2006, www.aaanet.org/ press/ASSCletter.htm (accessed July 11, 2007).

5. American Society for Engineering Education, Engineering Libraries Division, Scholarly Communication Committee, eld.lib.ucdavis.edu/scc.php (accessed July 11, 2007).

6. SPARC, Open Access Working Group, www.arl.org/sparc/ advocacy/oawg.html (accessed July 6, 2007); Alliance for Taxpayer Access, www.taxpayeraccess.org (accessed July 6, 2007).

7. International Coalition of Library Consortia, "Statement of Current Perspective and Preferred Practices for Selection and Purchase of Electronic Information" (Update No. 2, Pricing and Economics, October 2004), www.library.yale .edu/consortia/2004currentpractices.htm (accessed July 11, 2007).

8. Richard Fyffe and David Schulenberger, "Economics as if Science Mattered: The BioOne Business Model and the Transformation of Scholarly Publishing," Library Collections, Acquisitions, \& Technical Services 26, no. 3 (2002): 231-39.

9. Cornell University Library, Transforming Scholarly Communication and Libraries, "Faculty Senate Resolution," www.library.cornell.edu/scholarlycomm/resolution.html (accessed April 29, 2005); North Carolina State University Faculty Senate, "Resolution on Bundled Content and Elsevier," ncsu.edu/faculty_senate/resolutions/2003-2004/ resolution-2-2003-2004.php (accessed July 11, 2007); Indiana University, "Resolution on Journals, Databases, and Threats to Scholarly Publication," www.indiana.edu/ bfc/docs/AY04/ circulars/B39-2004.htm (accessed July 11, 2007).

10. Report of the CIC Summit on Scholarly Communication in the Humanities and Social Sciences, CIC Reports (Champaign, Ill.: Committee for Institutional Cooperation, 2004), www.cic.uiuc.edu/groups/CIC/archive/Report/ ScholarlyCommSummitReport_Feb04.pdf (accessed July 11, 2007).

11. University of Tennessee Scholarly Communications Committee, www.lib.utk.edu/colldev/schcomm.html (accessed July 11, 2007); Indiana University Committee on Scholarly Communication, www.indiana.edu/\%7Elibrcsd/ csc/index.html (accessed July 11, 2007); Cornell University Scholarly Communications Council, janusconference.library. cornell.edu/?p=90 (accessed Apr. 16, 2007).

12. Budapest Open Initiative, www.soros.org/openaccess (accessed July 11, 2007).

13. National Institutes of Health, Office of Extramural Research, NIH Public Access, publicaccess.nih.gov (accessed July 11, 2007).

14. Henry H. Barschall, "The Cost-Effectiveness of Physics Journals," Physics Today 41, no. 7 (July 1988): 56-59.

15. SPARC, SPARC Open Access Newsletter, www.arl.org/sparc/ soa/index.html (accessed July 11, 2007); Carl T. Bergstrom and Theodore C. Bergstrom, "The Economics of Scholarly Journal Publishing," octavia.zoology.washington.edu/publishing (accessed July 11, 2007); and Mark J. McCabe, "The Impact of Publishers Mergers on Journal Prices: An Update," ARL: A Bimonthly Report, no. 207 (December 1999), www.arl .org/resources/pubs/br/br207/br207jrnlprices.shtml (accessed July 11, 2007).

16. Cornell University Library, ArXiv.org (accessed July 11, 2007).

17. MIT Libraries, "What is DSpace at MIT?" libraries.mit.edu/ dspace-mit/about/definition.html (accessed July 11, 2007);

18. Clark Larsen, "AAPA Publishing Agreement," Physical Anthropology 4 (Spring 2000), www.physanth.org/newsletter/ spring00.pdf (accessed July 11, 2007).

19. Robin Peek, "Forty Editorial Board Members Resign from Kluwer Journal," Information Today (Oct. 22, 2001), newsbreaks.infotoday.com/nbreader.asp?ArticleID=17479 (accessed July 11, 2007). 
20. Anthony M. Cummings, et al., University Libraries and Scholarly Communication: A Study Prepared for The Andrew W. Mellon Foundation (Washington, D.C.: The Association of Research Libraries on behalf of The Andrew W. Mellon Foundation, 1992).

21. DSpace Federation Project, dspace.org/federation/project. html (accessed June 29, 2007); see also Final Report on the Initial Development of the DSpace Federation, June 30, 2004, dspace.org/federation/mellon-dspace.pdf (accessed June 29, 2007); Cornell University Library, DPubs: Digital Publishing System, dpubs.org/ (accessed June 29, 2007).

22. California Digital Library, eScholarship, www.cdlib.org/ programs/escholarship.html (accessed Dec. 21, 2007).

23. Stanford University, Highwire Press, highwire.stanford. edu/ (accessed April 16, 2007); Columbia University, EPIC Electronic Publishing Initiative@ Columbia, www.epic .columbia.edu (accessed July 11, 2007); University of Michigan, University Library, Scholarly Publishing Office, spo.umdl .umich.edu (accessed July 11, 2007); Cornell University, ProjectEuclid, projecteuclid.org/DPubS?Service=UI\&version $=1.0 \&$ verb $=$ Display\&handle $=$ euclid (accessed July 11, 2007).

24. Nancy Eaton, Bonnie MacEwan, and Peter J. Potter, "Learning to Work Together-The Libraries and the University Press at Penn State," ARL: A Bimonthly Report, no. 233 (April 2004), www.arl.org/bm doc/libpress.pdf (accessed July 7, 2007).

25. Cornell University, "Online Physics Archive That Is Transforming Global Science Communication, 'arXiv.org,' Is Moving from Los Alamos to Cornell University," www.news .cornell.edu/releases/July01/ginsparg.archive.ws.html (accessed Nov. 22, 2006).

26. PLoS: Public Library of Science, www.plos.org (accessed Dec. 21, 2008).

27. DOAJ: Directory of Open Access Journals, www.doaj.org (accessed July 11, 2007).

28. Berkeley Electronic Press, bepress: The New Standard in Scholarly Publishing, www.bepress.com (accessed July 11, 2007).

29. SPARC, Partners, www.arl.org/sparc/partner/index.html (accessed July 11, 2007).

30. Creative Commons, creativecommons.org (accessed July 11, 2007).

31. Leigh Estabrook, "The Book as the Gold Standard for Tenure and Promotion in the Humanistic Disciplines" (2003), www.cic.uiuc.edu/groups/CIC/archive/Report/ ScholarlyCommunicationsSummitReport_Dec03.pdf (accessed July 11, 2007).

32. John Unsworth and Pauline Yu, "Not-so-modest Proposals: What Do We Want Our System of Scholarly Communication to Look Like in 2010?" (paper presented at the CIC Summit on Scholarly Communications, Chicago, Dec. 2, 2003), www3.isrl .uiuc.edu/ unsworth/CICsummit.htm (accessed July 11, 2007).

33. Herbert Van de Sompel et al., "Rethinking Scholarly Communication: Building the System that Scholars Deserve," D-Lib Magazine (Sept. 2004), www.dlib.org/dlib/september04/ vandesompel/09vandesompel.html (accessed July 11, 2007).

34. Ibid.
35. Association of College and Research Libraries Scholarly Communication Committee, "Principles and Strategies for the Reform of Scholarly Communications," College \& Research Libraries News 63, no. 8 (Sept. 2003): 526-27, www .ala.org/ala/acrl/acrlpubs/whitepapers/principlesstrategies.htm (accessed July 11, 2007): 547.

36. For an example of a library committee charge, see the University of Washington Scholarly Communication Steering Committee, http://staffweb.lib.washington.edu/bob/Rcms_ new/ScholCom.html (accessed Dec. 21, 2007).

37. Association of College and Research Libraries, ACRL/ARL Institute on Scholarly Communication. www.ala.org/ala/acrl/ acrlissues/scholarlycomm/scinstitute.htm (accessed June 27, 2007); see also Association of Research Libraries, Scholarly Communication Institute, www.arl.org/sc/institute/instres. shtml (accessed June 27, 2007).

38. Association of College \& Research Libraries, "Scholarly Communication Toolkit," www.ala.org/ala/acrl/acrlissues/ scholarlycomm/scholarlycommunicationtoolkit/toolkit.htm (accessed July 11, 2007); Karen Williams, "The ACRL Toolkit Now Online: A Resource for Administrators, Faculty and Librarians," College \& Research Libraries News 66, no. 3 (2005): 199-201, www.ala.org/ala/acrl/acrlpubs/crlnews/backissues2005/march05/scholarlycommtoolkit.htm (accessed July 11, 2007).

39. Association of Research Libraries, "Library Brown-Bag Lunch Series: Issues in Scholarly Communication," www.arl.org/sc/ brownbag (accessed June 29, 2007).

40. SPARC, www.arl.org/sparc (accessed July 11, 2007).

41. University of Iowa, Harden Library for the Health Sciences, Hardin Scholarly Communication News, www.lib.uiowa.edu/ hardin/scholarly_comm_news.html (accessed July 11, 2007).

42. California Digital Library, eScholarship, www.cdlib.org/ programs/escholarship.html(accessed July 11, 2007); University of Virginia, IATH, Institute for Advanced Technology in the Humanities, www.iath.virginia.edu (accessed July 11, 2007).

43. Cornell University Library, Digital Consulting and Production Services, dcaps.library.cornell.edu (accessed July 11, 2007).

44. Deborah Lines Andersen, ed., Digital Scholarship in the Tenure, Promotion, and Review Process (Armonk, N.Y.: M.E. Sharpe, 2004); Joyce L. Ogburn, "Digital Scholarship," Against the Grain 15, no. 1 (2003): 20-22; John Unsworth, "The Crisis in Scholarly Publishing in the Humanities," ARL Bimonthly Report 228 (June 2003), www.arl.org/bm doc/ crisis.pdf (accessed Dec. 21, 2007); Abby Smith, New Model Scholarship: How Will It Survive? (Washington D.C.: Council on Library and Information Resources, 2003), www.clir.org/ pubs/reports/pub114/pub114.pdf (accessed July 11, 2007).

45. University of Washington Libraries, Digital Scholarship, www. lib.washington.edu/digitalscholar (accessed July 11, 2007).

46. Lizabeth A. Wilson, "Canary in the Coal Mine: Scholarly Communication and Libraries," (paper presented at the Association of College and Research Libraries Washington/ Oregon Conference, Corbett, Oregon, Oct. 28, 2004).

47. John P. Kotter, "Why Transformation Efforts Fail," Harvard Business Review 78, no. 2 (2000): 59-67. 